\title{
ANÁLISE PRELIMINAR DA ESTABILIDADE DE ENCOSTAS E TALUDES DE ALMIRANTE TAMANDARÉ E COLOMBO-PR
}

\author{
GIANE GIRALDI ARTUR*
}

\author{
DISSERTAÇÃO DE MESTRADO - Programa de Pós-Graduação em Geologia - UFPR \\ DATA DE DEFESA: 4 out. 1999
}

Na Região Metropolitana de Curitiba-PR, Brasil, a ocupação urbana desordenada, sem o prévio planejamento do uso e ocupação do terreno, vem causando perdas e danos sociais, econômicos e ambientais, a exemplo do que ocorre ao redor de outras metrópoles brasileiras. Um dos problemas é a movimentação de materiais inconsolidados em encostas, favorecidos por fatores geológicos e geomorfológicos, regime das chuvas, perda da cobertura vegetal, ações de ocupação urbana e mineração de calcário. Neste estudo procurase investigar a presença de movimentos gravitacionais em encostas e taludes, procurando indentificá-los em uma área situada na porção norte da referida região, determinando, na medida do possível, seus agentes, causas, geometria, parâmetros físicos de resistência

(ângulo de atrito interno f e coesão c), mecanismo de movimentação, natureza e estado dos materiais envolvidos. Procura-se, também, realizar uma análise preliminar da estabilidade de encostas e taludes da área de estudo, aplicando-se dois métodos de estabilidade, chegando-se à valores de $\mathrm{fe} c$ para os materiais constituintes destes. A partir destes valores, realizou-se uma estimativa do fator de segurança FS para encostas e taludes da área, e obteve-se valores de ângulos limites, isto é, de máxima inclinação, para estes. Espera-se, com este trabalho, poder ajudar um necessário gerenciamento da ocupação e uso do terreno da área pesquisada, principalmente em áreas onde as declividades superam $35^{\circ}$. Estas áreas são as mais sujeitas a riscos.

*E-mail: giane@ufpr.br 